\begin{tabular}{|l|l|l||}
\hline \multicolumn{2}{|c|}{ PublisherInfo } \\
\hline \hline PublisherName & $:$ & BioMed Central \\
\hline \hline PublisherLocation & $:$ & London \\
\hline \hline PublisherImprintName & $:$ & BioMed Central \\
\hline \hline
\end{tabular}

\title{
Antisense in Staphylococcus
}

\begin{tabular}{|l|l|l||}
\hline \multicolumn{2}{|c|}{ ArticleInfo } \\
\hline \hline ArticleID & $:$ & 4206 \\
\hline \hline ArticleDOI & $:$ & $10.1186 /$ gb-spotlight-20010921-01 \\
\hline \hline ArticleCitationID & $:$ & spotlight-20010921-01 \\
\hline \hline ArticleSequenceNumber & $:$ & 277 \\
\hline \hline ArticleCategory & $:$ & Research news \\
\hline \hline ArticleFirstPage & $:$ & 1 \\
\hline \hline ArticleLastPage & $:$ & 2 \\
\hline \hline & & RegistrationDate : 2001-09-21 \\
ArticleHistory & $:$ & OnlineDate $\quad$ 2001-09-21 \\
\hline \hline ArticleCopyright & $:$ & BioMed Central Ltd2001 \\
\hline \hline ArticleGrants & $:$ & \\
\hline \hline ArticleContext & $:$ & 130592211 \\
\hline \hline
\end{tabular}




\section{Jonathan B Weitzman}

Email: jonathanweitzman@hotmail.com

Although many gene-inactivation technologies have been applied to bacterial genetics, the potential for using antisense technology has not been extensively explored. In the September 21 Science, Yindo Ji and colleagues from GlaxoSmithKline Pharmaceuticals in Collegeville, Pennsylvania, describe a comprehensive genomic analysis of the human pathogen Staphylococcus aureus using a regulated antisense strategy (Science 2001, 293:2266-2269). They used an adapted tetracycline-dependent (tet) regulatory system to drive the expression of small fragments of sheared DNA. Colonies were selected that grew in the absence of anhydrotetracycline but not when expression was induced. About $3 \%$ of colonies were growth-defective or lethal upon induction, and about a third of these contained singleORF antisense constructs. This method allows easy isolation and maintenance of conditional growthdefective strains, and rapid identification of the relevant gene. Ji et al.identified over 150 genes that are critical for growth and survival, and are potential targets for antibiotic discovery. A third of these genes encode for proteins of unknown function. Each of the bacterial strains generated offers a titratible system to investigate the bacterial growth phenotype and the role in infection.

\section{References}

1. An antisense approach to phenotype-based gene cloning in Tetrahymena

2. Science, [http://www.sciencemag.org]

3. GlaxoSmithKline Pharmaceuticals, [http://www.gsk.com] 